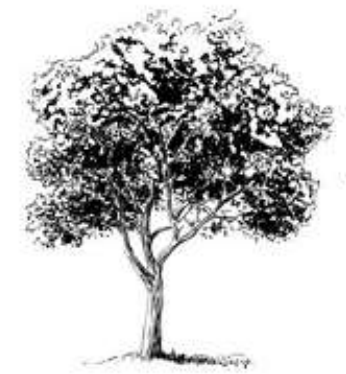

ISSu 2176-5960

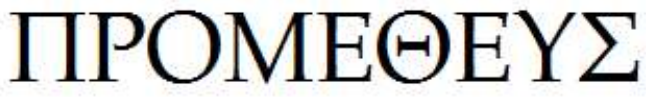

Journal of Philosophy

n. 32 Janeiro Abril de 2020

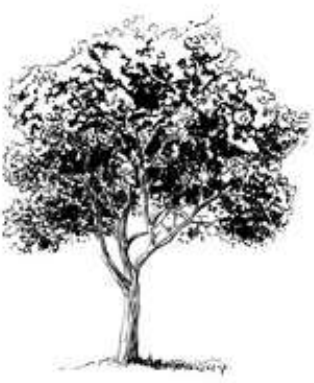

\title{
O PORDĒ DE CRATES E A CONVERSÃO DE METROCLES À FILOSOFIA CÍNICA
}

\section{Brenner Brunetto Oliveira Silveira Mestrando em Filosofia - Universidade Federal de Goiás}

RESUMO: $O$ presente trabalho tem como finalidade investigar uma anedota contada por Diógenes Laércio no Capítulo 6 do Livro VI de sua obra Vidas e Doutrinas dos Filósofos Ilustres. Nela, Diógenes nos conta uma história sobre Metrocles, um peripatético discípulo de Teofrasto, que certo dia enquanto fazia exercícios na academia de ginastica soltou um peido involuntariamente.

PALAVRAS-CHAVE: Cinismo, Crates de Tebas, Peido.

ABSTRACT: The present work aims to investigate an anecdote told by Diogenes Laertius in Chapter 6 of Book VI of his Lives and Opinions of Eminent Philosophers. In it, Diogenes tells us a story about Metrocles, a peripatetic disciple of Theophrastus, who one day while doing exercises in gymnastics school he unleashed a fart.

KEYWORDS: Cynicism. Crates of Thebes. Fart. 
Crates de Tebas é uma das três grandes figuras do cinismo grego ${ }^{1}$. Segundo a tradição antiga, ele foi discípulo de Diógenes, o Cão. ${ }^{2}$ Conta-se também que Crates tinha uma grande porção de terras e que tinha muitos bens. No entanto, o mesmo abandonou suas terras e arremessou seus bens ao mar assim que adentrou na filosofia cínica. $^{3}$ Após ter se tornado um filósofo famoso, ele veio a ser bastante adorado por seus concidadãos ${ }^{4}$ e os mesmos frequentemente chamavam Crates para resolver problemas domésticos ou para fazer refeições em suas casas. Por este motivo Crates de Tebas recebeu o apelido de Abridor de Portas. ${ }^{5}$ Deste modo, pode-se dizer que, os atenienses tinham pelo nosso filósofo uma grande admiração e o levavam em alta conta.

Diógenes Laércio também nos conta que Crates fora casado com Hipárquia. Segundo a tradição, a mesma ao apaixonar-se pelo filósofo, ameaçou colocar um fim em sua própria vida caso seus pais não lhe dessem permissão de casar-se com o filósofo. Com isto, Crates foi chamado para resolver a situação. Chegando ao local, o mesmo despiu-se e disse à Hipárquia "Eis o futuro esposo, e aqui estão os seus bens; decide, portanto, pois não poderá ser a minha consorte se não te adaptares ao meu modo de viver" (D.L. VI. 96). No entanto, isto não fez com que a donzela sentisse repulsa por nosso filósofo, ao contrário, fez com que ela aceitasse "seus bens". O espírito da jovem persuadiu o filósofo, e com isto, eles se casaram e tiveram uma kynikogamia. ${ }^{6}$

A jovem Hipárquia, segundo Diógenes Laércio, tinha um irmão chamado Metrocles. Em sua Vida de Metrocles ouvimos uma história bastante inusitada acerca da conversão do cunhado de Crates ao cinismo. O mesmo nos diz que:

Inicialmente [Metrocles] foi discípulo do peripatético Teofrasto, e era tão débil fisicamente que certa vez, enquanto fazia exercício na escola, soltou um peido; envergonhado com essa falta, trancou-se em casa pretendendo morrer de inanição. Tomando conhecimento de sua atitude desesperada, Crates, atendendo a uma solicitação, foi visita-lo; depois de fazer propositalmente uma refeição de tremoços, tentava persuadir Metrocles com bons argumentos de que este nada fizera de mal, e que seria de admirar se não houvesse proporcionado aos gases

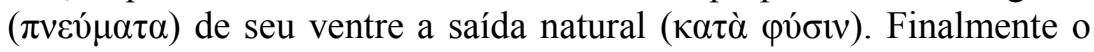

\footnotetext{
${ }^{1}$ As outras duas figuras são Diógenes (mestre de Crates) e Antístenes (considerado por alguns autores mestre de Diógenes e, por outros autores, como precursor ou inspirador da escola cínica).

${ }^{2}$ D.L. VI. 85.

${ }^{3}$ Id. Ib. 87.

${ }^{4}$ Uso o termo concidadão aqui no sentido tradicional da palavra, pois Crates, conforme sabemos, considerava apenas Diógenes de Sinope como seu concidadão (D.L. VI. 93).

${ }^{5}$ D.L. VI. 86.

${ }^{6}$ Diógenes Laércio relata que após o casamento, Hipárquia adotou o estilo de vida cínico (D.L. VI. 96 ff).
} 
próprio Crates soltou um peido, e, consolando-o com o fato de ele também haver cometido a mesma falta, conseguiu reanimá-lo. Daí em diante Metrocles tornou-se discípulo de Crates e atingiu uma posição de relevo na filosofia. (D.L. VI. 94)

Por mais absurda e engraçada que tal história possa ser, ela pode nos revelar informações extremamente importantes acerca da própria filosofia cínica. Para que possamos realizar tal empresa, deveremos analisar tal anedota frase por frase. Com isto, pode surgir a pergunta: "Mas porque deveremos verificar aspectos filosóficos numa história de vida de um filósofo?" Creio que a resposta a tal pergunta foi brilhantemente respondida por A.A. Long numa passagem longa, porém eternamente memorável, na qual ele diz:

A vida de Crates, portanto, deve ser vista como uma contribuição à ética helenística, assim como a de Diógenes. Há uma tendência, no estudo atual da ética grega, de ignorar as biografias, com base em que o historiador filosófico deve restringir sua atenção à analise formal de conceitos morais. No caso de filósofos da tradição socrática, vida e pensamento estão muito estreitamente relacionados para que tal restrição seja defensável. A pressuposição é de que o filósofo está tão interessado na felicidade quanto os seus ouvintes, e de que as razões que ele pode lhes oferecer para viver de uma determinada maneira são razões que ele próprio acha suficientemente convincentes para leva-lo a agir com base nelas. Se Diógenes e Crates, ou, do mesmo modo, Pirro, Zenão, Arcesilau e Epicuro, não vivessem de um modo que fosse amplamente coerente com o seu pensamento oficial, sua filosofia ficaria completamente desacreditada. (LONG, 2007, p. 39.)

Com este procedimento em vista, conseguiremos chegar ao cume de nossos propósitos. Passemos então a tal análise.

\section{Metrocles, o Peripatético}

Conforme dito acima, iremos realizar um procedimento de dissecação desta anedota, frase por frase, para que possamos conseguir concluir nossa proposta, a saber: identificar, dentro de tal anedota, um leque de conceitos-chaves da filosofia cínica como um todo. A primeira frase nos diz que Metrocles era discípulo do Teofrasto, o primeiro escolarca do Liceu após a morte de seu fundador Aristóteles. Também somos informados que o próprio Metrocles era fisicamente fraco, e que, por este motivo, de maneira involuntária, soltou um peido na escola de ginástica enquanto realizava seus exercícios. Tal peido saiu involuntariamente tendo em vista que seu corpo não aguentou a quantidade de força que o mesmo estava realizando em tal exercício. Devido a isto, o irmão de Hipárquia fícou extremamente envergonhado e se trancou em casa. A 
vergonha foi tão forte, que Metrocles chegou ao ponto de querer morrer, ou seja, para ele a vergonha a que fora submetido era pior do que a própria morte. Por hora, paremos neste ponto e analisemos tais informações com cuidado. $\mathrm{O}$ fato de Metrocles ser um peripatético e não ter conseguido superar tal vergonha nos leva a uma pergunta: o que a filosofia peripatética teria a oferecer à Metrocles? Ou seja, como ela poderia ajudá-lo?

Sabemos que um dos maiores debates éticos da antiguidade foi o que ocorreu entre os peripatéticos e os estoicos acerca do papel da virtude para a felicidade. ${ }^{7}$ Para os últimos, a virtude era necessária e suficiente, mas para os primeiros a virtude era necessária para a felicidade, porém ela não era suficiente. Para que possamos entender melhor esse ponto, se faz necessário uma regressão até o fundador do Liceu. Aristóteles tornou esse problema memorável quando introduziu o famoso "problema de Príamo". 8 Para o discípulo de Platão, o virtuoso rei de Troia não pode ser considerado uma pessoa feliz tendo em vista o fim trágico que ocorreu em sua vida, pois como se sabe o mesmo teve o seu reino tomado e sua família assassinada, ou seja, Aristóteles diz que "ninguém apontaria como feliz alguém que se vê diante de reveses da sorte como os dele e que acabou padecendo de um fim miserável.” (Ética a Nicômaco, I. 8. 1100a5-9, tradução nossa). Aristóteles chega a tal conclusão devido ao seu conhecido método dialético, pois ao realizar a formulação de sua concepção de felicidade ele considera tanto as opiniões dos antigos filósofos quanto as opiniões populares, realizando assim uma síntese. Com isto, para o fundador do Liceu a virtude é condição necessária para a felicidade, ou seja, sem ela não há possibilidade alguma de que uma pessoa possa ser considerada feliz. Por outro lado, ele também considera a opinião popular, a saber: que para ser feliz se faz necessário ter bens corpóreos (beleza, força, saúde e etc.) e também ter bens externos (riqueza, honra e etc.). ${ }^{9}$ Diógenes Laércio, ao escrever a Vida de Aristóteles também ressalva a importância dessa ideia para o mestre de Alexandre, o Grande. ${ }^{10}$

O sucessor de Aristóteles, Teofrasto prosseguiu com a discussão em questão. Sabemos por intermédio de Cícero que Teofrasto foi quem mais enfatizou a questão dos

\footnotetext{
${ }^{7}$ Para um exame detalhado deste debate ver Daniel Russel em Happiness For Humans, Part 2,

${ }^{8}$ Cf. Happiness For Humans, 2012, pg. $108 \mathrm{ff}$.

${ }^{9}$ Cf. Ética a Nicômaco I. 8. 1098b10-16.

${ }^{10}$ D.L. V. 30: “Como fim único Aristóteles propôs o exercício da excelência em uma vida perfeita. Definia a felicidade como a fusão perfeita de bens de três espécies; dos bens da alma, que qualifica de primeiros por sua importância; em segundo lugar dos bens do corpo - a saúde, a força, a beleza e similares -; em terceiro lugar os bens externos - a riqueza, a nobreza de nascimento, a fama e similares -; a excelência não é suficiente para a felicidade, sendo necessário ainda os bens do corpo e os externos, pois o sábio será infeliz se viver aflito por causa de sofrimentos, pobreza ou similares; a deficiência moral, entretanto, é suficiente em si mesma para causar a infelicidade, ainda que seja acompanhada por abundantes bens externos e do corpo".
} 
bens externos na ética. Cícero nos diz que para o discípulo de Aristóteles grandes males ocorridos nos bens externos ou nos bens corpóreos possuem grande poder sobre a felicidade de um indivíduo. ${ }^{11}$ Deste modo, pode-se dizer que:

Parece inegável que Teofrasto e Licón levem muito a sério a ideia de que há bens além da atividade virtuosa que desempenham um papel crucial na felicidade da pessoa virtuosa (ou seja, a tese da dependência). E, afinal de contas, é justamente essa ideia que torna tão difícil supor que Príamo poderia ser feliz. (RUSSEL, 2012, p. 118, tradução nossa)

Com esta informação em mãos, podemos presumir que Teofrasto considerou os bens externos muito mais do que seu mestre Aristóteles. Para Teofrasto "as coisas ruins têm um poder de arruinar a vida, e elas não se limitam a atividades ruins, mas incluem todos os três tipos de males, tais como tristeza (mental), espancamentos (corporal) e banimento (externo)" (RUSSEL, 2012, p. 118, tradução nossa). ${ }^{12}$

Com estes dados podemos prosseguir na análise da anedota. Podemos supor que Metrocles aprendeu a ética peripatética conforme os desenvolvimentos propostos por Teofrasto. Sabemos também que o irmão de Hipárquia era débil fisicamente, ou seja, ele não possuía bens corpóreos. Ele também sofreu escárnio das pessoas que estavam no ginásio ao vê-lo soltando o peido involuntariamente, ou seja, ele perdeu sua honra, ele perdeu os bens externos. Ele também padeceu de uma extrema vergonha, tendo em vista o escárnio público, ou seja, ele não tinha bens da alma. Deste modo, podemos nos perguntar novamente: o que a ética aristotélica poderia oferecer ao pequeno filósofo? Qual remédio terapêutico ela poderia oferecê-lo para que ele não se matasse? A resposta, infelizmente, é negativa. A ética aristotélica não dispunha de meios que pudesse ajudá-lo a encarar tal problema. A ética aristotélica já exige do indivíduo uma certa "preparação" desde criança e também exige uma espécie de sorte. A conclusão é que o filósofo peripatético, mesmo que possua a mediania, está inevitavelmente sujeito

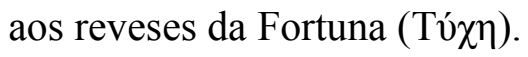

\section{A Filantropia de Crates, o Abridor de Portas}

Após tal análise acerca das características peripatéticas de Metrocles e o fraco poder da ética aristotélica para ajudar o irmão de Hipárquia, passemos então a próxima frase. Logo após esta introdução, Diógenes Laércio nos diz que o discípulo do

\footnotetext{
${ }^{11}$ De Finibus V. 77, 84-86.

${ }^{12}$ Ver também a discussão levantada por Julia Annas em The Morality of Happiness, 1993, p. 385-411.
} 
sinopense falsificador de moedas fora chamado para controlar a situação. Podemos supor que nesta época Crates ou 1) já conhecia e era casado com Hipárquia, e, consequentemente o pedido de socorro fora feito por sua própria esposa; 2) ou Crates ainda não a conhecia e o pedido de socorro fora feito pelos próprios pais de Metrocles e Hipárquia. É bastante provável que a segunda alternativa seja a correta, pois no Capítulo 7 do Livro VI de Diógenes Laércio, conforme dito no início deste artigo, somos informados que os próprios pais de Hipárquia foram ao encontro de Crates pedir-lhe socorro quando a mesma ameaçou matar-se caso não se casasse com o professor de Zenão (D.L. VI. 96). Deste modo, é bem provável que um dos "gatilhos" do louco amor que Hipárquia sentia por Crates tenha sido motivado pelo fato do filósofo ter atendido tal pedido para seu irmão e conhecido Crates e sua filosofia cínica através deste dia. ${ }^{13}$

Porém tal frase não nos revela apenas este fato histórico. Ela também reforça o fato mencionado por Diógenes Laércio, a saber: o apelido de Crates. Conforme dito, Crates era conhecido como Abridor de Portas. No entanto, existe algo muito mais profundo no fato histórico acerca de Crates ser o Abridor de Portas, pois dentro deste fato histórico existe um fato filosófico, a saber: a $\varphi \imath \lambda \alpha v \theta \rho \omega \pi i ́ \alpha$ de Crates de Tebas. Ou seja, o mais importante - filosoficamente falando - é o motivo pelo qual Crates recebera tal apelido. Segundo Navia:

Ele [isto é, Crates] mergulha em uma intensa vida de atividade social, quase como se ele fosse movido por um espírito de empreendimento missionário. O cerne deste empreendimento pode ser discernido no que ele chamou de sua "filantropia" ( $(\lambda \lambda \alpha v \theta \tau \rho \omega \pi i ́ \alpha)$, uma palavra que parece ter sido cunhada por ele, pois pelo menos não é encontrada em nenhum contexto antes dele. Literalmente significa "o amor pelas pessoas" e, por associação, inclui ideias como bondade, benevolência e clemência. Seus cognatos modernos (por exemplo, "filantropia") transmitem, naturalmente, um significado relacionado, mas mais no sentido de "caridade", como quando falamos de pessoas ricas dando grandes contribuições para uma "causa de caridade" (que, na linguagem dos cínicos, teria sido dito assim: "Pessoas ricas despejando suas migalhas sobre os pobres"). Em inglês, a palavra "filantropia" parece ter sido usada pela primeira vez em um dos sermões de Jeremy Taylor, um pregador inglês por volta de 1650, e desde então seu senso moderno de "caridade" (tanto em inglês quanto em outras línguas) se estabeleceu. O significado do termo grego, no entanto, é um pouco diferente, pois representa o amor pelas pessoas, pelas pessoas individuais ou o amor pela humanidade em geral. (NAVIA, 1996, p. 128, tradução nossa)

\footnotetext{
${ }^{13}$ Dudley possui uma visão um pouco diferente. Ele acredita que Crates conheceu Hipárquia por intermédio do próprio Metrocles (1937, p.49). Tal suposição é bastante plausível, porém difícil de se afirmar com certeza tendo em vista a escassez das fontes.
} 
E também Dudley:

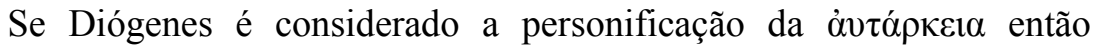
Crates pode representar aquela $\varphi \imath \lambda \alpha v \theta \tau \rho \omega \pi i ́ \alpha$, simbolizada de várias maneiras nas concepções do Cínico como o Cão de Guarda, como Doutor, ou como Escoteiro, trabalhando nos interesses da humanidade. "Ele entrava em qualquer casa", diz Plutarco e eles o recebiam de bom grado e com honra e, portanto, ele foi apelidado de

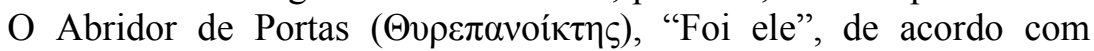
Juliano, "quem foi o originador das nobres doutrinas de Zenão." E dizem que, por sua causa, os gregos escreveram por cima das portas "Entrada para Crates, o Bom Gênio." (DUDLEY, 1937, p. 43, tradução nossa)

Com isto, fica esclarecido o motivo pelo qual Crates de Tebas recebeu o codinome de Abridor de Portas, ou seja, pela sua filantropia, isto é, pelo seu modo amável de tratar as pessoas, por ser o "amigão da vizinhança”, mas acima de tudo, pelo seu interesse ético pela humanidade. Cabe uma pergunta: Estamos autorizados a dizer que não havia filantropia em Antístenes e/ou em Diógenes de Sinope? Ou seja, há filantropia no cinismo somente com (ou à partir de) Crates? Obviamente, este não é o objetivo deste artigo, mas podemos responder de forma rápida, à saber: Há filantropia tanto em Antístenes quanto em Diógenes, pois o cinismo, conforme dito por Diógenes Laércio, não se interessava por lógica ou física, mas tão somente por ética. ${ }^{14} \mathrm{Ou}$ seja, o cinismo é uma filosofia preocupada somente com os assuntos humanos. Seu interesse é mostrar ao homem o caminho para que ele saia das ilusões impostas pelas convenções humanas e atinja a liberdade e a felicidade. Sem este objetivo o cinismo seria tão somente uma espécie misantropia filosófica. $\mathrm{O}$ fato de Crates ter sido reconhecido como filantropo se deve ao seu modo de filosofar, que era diferente do de Antístenes ${ }^{15}$ e Diógenes. $^{16}$

Podemos salientar também que Crates, ao passar de casa em casa, para ajudar as pessoas, não tinha como objetivo final "produzir pequenos cínicos, como no sentido

\footnotetext{
${ }^{14}$ D.L. VI. 103.

${ }^{15}$ Antístenes era bastante conhecido por bater e por tratar mal seus discípulos. Ao ser questionado por que ele era tão rude com seus discípulos ele respondeu: "Os médicos também agem de maneira idêntica com seus pacientes" (D.L. VI. 4). Ou seja, tal frase já mostra que seu "tratamento de choque" não era realizado pelo fato dele odiar as pessoas, mas pelo fato de ser um método que, segundo seu ponto de vista, era necessário realizar para retirar as pessoas de seu estado de doença, isto é, de sua ignorância.

${ }^{16}$ Quanto a Diógenes, são muitas as anedotas nas quais ele aparentemente mostra desdém pela raça humana conforme relatado em todo o capítulo dedicado ao filósofo por Diógenes Laércio. No entanto, da mesma forma que no caso de Antístenes, isto é devido à forma de Diógenes filosofar, a saber: pela sua performance retórica. Para a retórica de Diógenes ver BRANHAM, Richard B. "Desfigurar a moeda. A retórica de Diógenes e a invenção do cinismo." In: BRANHAM e GOULET-CAZÉ (Orgs). Os cínicos. O movimento cínico na Antiguidade e o seu legado (2007).
} 
literal de $\pi \alpha 1 \delta \alpha \gamma \omega \gamma o ́ \varsigma$, largos em um sentido figurado, o cínico não trabalha em nome de seu movimento, mas da humanidade" (DUDLEY, 1937, p. 88, tradução nossa). No entanto, se ele percebesse que um certo indivíduo tinha uma certa "tendência" para o cinismo, indivíduo este que poderia "entoar a nota mais alta" (D.L. VI. 34) e que poderia "desfigurar a moeda corrente" então ele faria de tal indivíduo um cínico, para que ele possa, posteriormente, suceder-lhe na guerra contra o mundo.

Outro ponto interessante que podemos notar também está no fato de Crates ter comido uma sopa de tremoços propositalmente. Isto nos mostra um contraste entre Crates e seu mestre Diógenes, pois sabemos por meio de Diógenes Laércio que o sinopense era extremamente hábil em improvisações, ${ }^{17}$ seja para responder verbalmente ou para realizar algum ato. Ao que parece, ou Crates não tinha o mesmo manejo que seu mestre ou ele já previa que não conseguiria persuadir Metrocles via argumentação. Neste caso, ter-se-ia que persuadi-lo via ação.

\section{A Parrhesia e a Anaídeia de Crates}

Passemos adiante e prossigamos em nossa investigação. Durante a conversa com Metrocles, Crates argumentou com o pobre rapaz que o fato ocorrido não era algo estranho, pois estranho seria se ele tivesse realizado o ato de uma maneira não natural. No entanto, tal conversa não surgiu efeito terapêutico sobre o rapaz e por este motivo Crates soltou um peido. Com este ato, Metrocles ficou boquiaberto com o fato de que uma pessoa tão importante e tão conhecida como Crates tenha feito tal ato. Um simples ato deixou Metrocles tão desconcertado que estamos autorizados a dizer que ele teve a mesma sensação que Mênon teve ao ser vítima da impiedosa dialética de Sócrates. ${ }^{18}$

A sensação de espanto de Metrocles se deve ao fato de que ele ainda estava

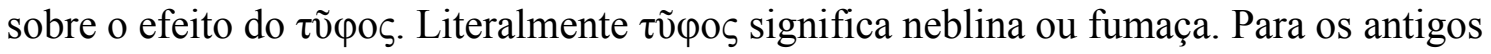

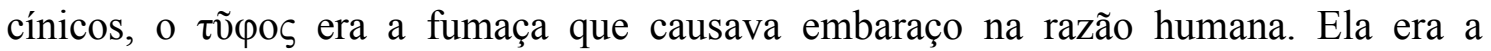
responsável pelas opiniões errôneas das pessoas, pelas paixões violentas que assolam a

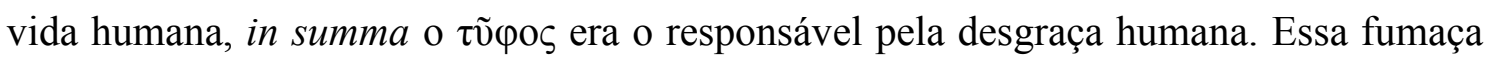
tinha uma gênese, sua gênese é o vouós, ou seja, as convenções. Tais convenções

\footnotetext{
${ }^{17}$ D.L. VI. 74.

${ }^{18}$ Mênon 80a-b. Lá Mênon confessa à Sócrates que já ouvira a respeito de Sócrates muitas vezes antes de conhece-lo, e diz que todas as histórias contavam sobre como as pessoas ficavam num estado de perplexidade após conversar com o filósofo e conclui que agora é ele mesmo quem está em tal estado. Por fim ele compara o mestre de Platão com a raia elétrica, pois todos que se aproximam dela ficam entorpecidos, tal como os interlocutores de Sócrates.
} 
podem ser sociais/culturais, religiosas, políticas e até mesmo filosóficas. ${ }^{19} \mathrm{~A}$ ideia de

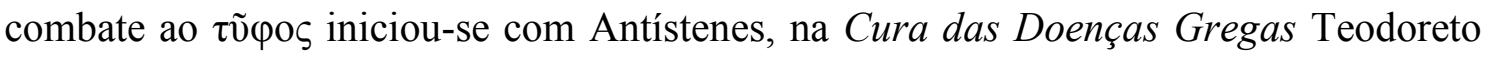

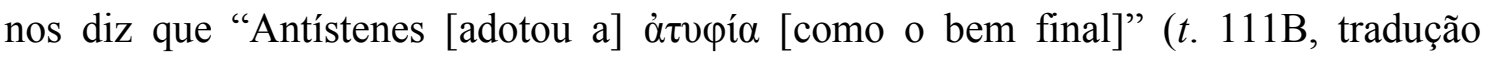

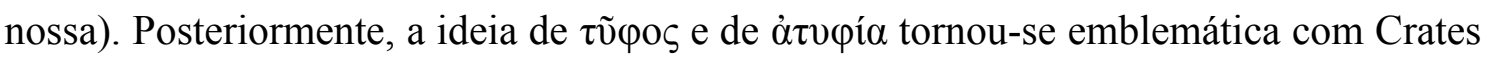
e sua cidade, no qual se lê:

Existe uma cidade, Pera, envolta em vapores escuros ( $\tau$ ṽ $\varphi \varsigma)$, cor de vinho, bela e fértil, suja e carente de tudo. Não navegam até lá, nem tolos, nem parasitas, nem glutões, que se regalam com as nádegas das prostitutas. Mas a cidade produz timo, alho, figos e pães; seus habitantes não se digladiam por essas coisas, nem recorrem às armas por dinheiro ou pela glória." (D.L. VI. 85)

Podemos ver, claramente, que a cidade de Pera $^{21}$ é uma cidade desprovida de $\tau \tilde{\varphi} \varphi \varsigma_{\zeta}$, pois o $\tau \tilde{\varphi} \varphi \varsigma_{\zeta}$ está somente ao seu redor, ou seja, nas demais cidades. Por este motivo que a cidade não possui tolos, nem glutões, nem pessoas luxuriosas e muito menos disputas por glória, dinheiro e poder. A cidade possui somente o necessário para a sobrevivência humana. Ou seja, a cidade de Pera é uma utópica cidade, tal como a República de Platão, uma cidade ideal, na qual os seres humanos viveriam conforme a natureza. Para Navia:

O objetivo da filosofia, na verdade seu único propósito, diria Crates, é

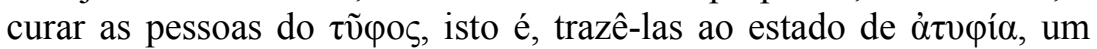
estado no qual todas as condições ideais cínicas da existência humana são encontradas como se fosse um somatório do cinismo clássico: liberdade das restrições sociais e tradicionais, autossuficiência, indiferença às vicissitudes da vida, autocontrole e frugalidade, disciplina e resistência, força de caráter e todo o resto. Na ḋtupía, então, nos deparamos com o summum bonum dos cínicos, como é especialmente evidente ao considerarmos as doutrinas e o exemplo de Crates. Decleva Caizzi afirma sucintamente, quando ela observa que "o objetivo do filósofo é a obtenção da atyphia". Este objetivo não é, em princípio, completamente diferente daquele que filósofos genuínos, cínicos e outros, buscaram. Representa a purificação da mente de todos os pensamentos desnecessários e perturbadores, a remoção de ideias inconsequentes e mal concebidas, o abandono de impedimentos e obstáculos que confundem a consciência humana e a obtenção de um estado duradouro de lucidez intelectual e espiritual. Isto é, simplesmente afirmado, a utopia sobre a qual Crates sonhou, sua ilha de Pera. (NAVIA, 1996, p. 139, tradução nossa)

\footnotetext{
${ }^{19}$ Em D.L. VI. 7 vemos Antístenes acusando Platão de possuir tũ фoç e em D.L. VI. 26 vemos Diógenes, o Cão fazer a mesma acusação.

${ }^{20}$ Variações nossa.

${ }^{21}$ Trocadilho com a famosa sacola $(\pi n \dot{\rho} \alpha)$ que o cínico carregava.
} 
Agora, temos que investigar quais são os meios que o cínico dispõe para limpar

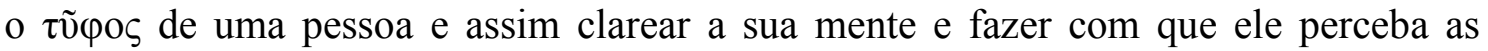
mazelas deixadas pelas convenções irracionais impostas pela sociedade. Se fosse um

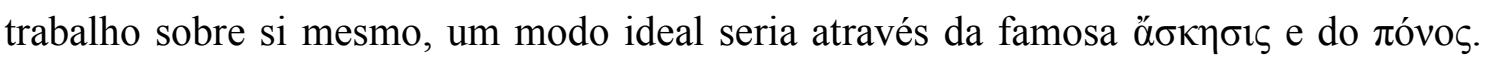
No entanto, como era um trabalho para outro então poderia ser realizado de dois modos: 1) via argumentação ou 2) via ação. A via argumentativa se dá através da famosa $\pi \alpha \rho \rho \eta \sigma i ́ \alpha$, ou seja do falar verdadeiro do cínico. ${ }^{22}$ A via da ação se dá através da

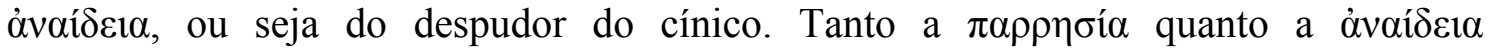
simbolizam a $\dot{\imath} \lambda \varepsilon v \theta \varepsilon \rho i ́ \alpha$ (liberdade) do cínico perante as convenções, sendo a $\pi \alpha \rho \rho \eta \sigma i ́ \alpha$ a liberdade da fala e a $\alpha$ voí $\delta \varepsilon ı \alpha$ a liberdade da ação.

Podemos dizer que a $\pi \alpha \rho \rho \eta \sigma i ́ \alpha$ cínica possui uma certa restrição, pois conforme dito ela se reduz a dizer a verdade e a chamar as coisas pelo seu nome correto em qualquer lugar, em qualquer tempo e para qualquer pessoa. Foi exatamente isso que Crates fez ao dizer à Metrocles que não havia nada de estranho pelo fato dele ter soltado um peido, pois estranho seria se ele tivesse soltado o peido de um modo não natural. $\mathrm{Ou}$ seja, o que Crates quer salientar é que o fato de sentirmos vergonha por um ato tão natural como peidar se dá pelo fato de nós estarmos presos à convenções de etiqueta. Tais convenções não existem por natureza. Elas são nossas próprias criações, tais como tantas outras. E tais criações são as responsáveis por fazer com que nós tenhamos vergonha de realizar um ato tão comum ao ser humano. Ou seja, é completamente irracional que nós tenhamos vergonha de fazer um ato que por natureza é comum. Nós estamos negando a nossa natureza ao sentir vergonha dela.

No entanto, conforme relatado, Metrocles não foi convencido via argumentação. E por este motivo Crates soltou o seu principal argumento: um peido. Tal ato de fato representa o principal argumento cínico e demonstra o seu método mais característico.

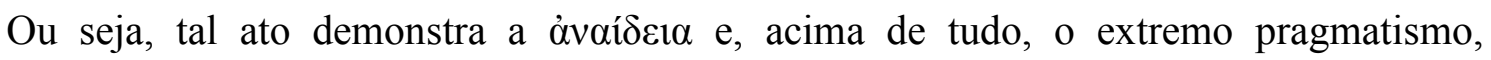
característico do cinismo.

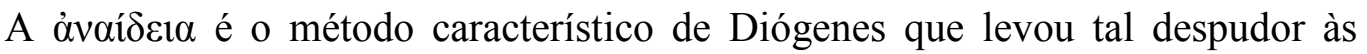
últimas consequências. Sabemos também que o mestre de Crates utilizava muito suas flatulências para demonstrar a insanidade do mundo, pois conforme Krueger:

Juliano conhecia histórias sobre Diógenes soltando flatulências em público, e Laércio afirma que Diógenes escreveu uma obra chamada

\footnotetext{
${ }^{22}$ Para um relato extenso e bastante inspirador sobre a $\pi \alpha \rho \rho \eta \sigma i \alpha$ no cinismo antigo ver o curso de 1984 de Foucault no Collége de France.
} 
Pordalos, cujo título é certamente derivado da palavra grega pordē (flato). Epicteto lamentou que os cínicos de segunda classe de sua época não imitassem seus mestres em nada além de peidar. Flatos também aparecem numa história contada sobre o sucessor de Diógenes, Crates, que converteu Metrocles, o irmão de Hipárquia, ao cinismo depois de comer favas e soltar gases. As favas eram um legume famoso por produzir gases, com a equivalência cultural de nosso feijão cozido. Parece que Diógenes e seus seguidores comiam favas religiosamente, em especial em discursos públicos, onde criavam uma distração visual e, um pouco depois, podiam também oferecer ao público uma distração auditiva e olfativa. (KRUEGER, 2007, p. 249.)

E também, mais à frente, ele comenta, de uma maneira cirúrgica e brilhante, uma passagem onde Juliano relata uma história envolvendo Diógenes, um garoto e um flato, segundo ele:

O Diógenes de Juliano sentia que era sua obrigação refutar os equívocos sobre o comportamento que seria natural para nos humanos. Os instrumentos dessa refutação eram as funções naturais para o corpo humano. Juliano relata a seguinte história: "Certa vez, quando Diógenes estava numa multidão de pessoas, um certo jovem peidou. Diógenes cutucou-o com seu bastão e disse, 'E então, desprezível infeliz, embora não tenhas feito nada que lhe desse o direito de tomar tais liberdades em público, estás começando aqui e agora a mostrar o seu desprezo pela opinião $[$ doxa $]$ ?"'. Aqui, o próprio Diógenes explica indiretamente método cínico para aceitar a opinião convencional: ele vê a emissão de flatos como um comentário social, igual à liberdade de fala ou qualquer outra forma de expressão humana de insatisfação. Diógenes ataca o jovem não pelo ato de soltar flatos em público, mas por fazê-lo sem expressar desprezo pela sociedade. Os cínicos usam as funções corporais como uma linguagem de protesto. No entanto, como esse exemplo mostra, a vulgaridade por si só não faz de alguém um cínico. O jovem não havia ganhado o privilégio de realizar tal ato, uma vez que não fizera nada mais para rejeitar a vida comum. A ironia da história, claro, é que o jovem não tinha nenhuma intenção de registrar uma objeção à ordem social. Seu ato foi, por assim dizer, inocente. Para Diógenes, porém, tal ato, era um elemento explícito de seu vocabulário. Assim, temos Diógenes mais uma vez apresentando um comportamento vulgar: cutucando um jovem em público e, dessa forma, chamando atenção para um ato natural que o jovem sem dúvida teria preferido que passasse despercebido. (KRUEGER, 2007, p. 256.)

Aqui, notamos claramente a diferença proposta antes entre o método mais filantrópico de Crates e o método mais despudorado de seu mestre. Estamos autorizados a dizer que, se fosse Diógenes quem tivesse sido chamado para conversar com Metrocles, é bem provável que ele iria utilizar métodos bem mais "fortes" 23 com o jovem.

\footnotetext{
${ }^{23}$ Provavelmente através do humor, com alguma piada mordaz, que lhe era característico.
} 
Por outro lado, apesar do despudor ser característico de Diógenes, isso não significa que ele não foi usado por outros filósofos cínicos, pois é nele que se encontra o argumento mais forte do cínico, onde de fato ele zomba, debocha e tira escárnio das convenções irracionais das quais nós somos ao mesmo tempo algozes e vítimas. E tal despudor demonstra o extremo pragmatismo da escola. Conforme ressaltado por Antístenes "a excelência está nas ações e não necessita de muitas palavras" (D.L.VI. $11)$.

Deste modo, podemos concluir que o melhor argumento, neste caso, não se dá através de silogismos sofisticados, ou através de embelezados discursos retóricos feitos com a finalidade de persuadir o rapaz. O mais colossal dos argumentos, neste caso, é um simples ato de peidar. Tal ato, deixa para trás qualquer tipo de argumentação.

\section{Conclusão: Metrocles, o Cínico}

Chegamos ao fim de nossa jornada. E no fim desta anedota recebemos a informação de que Metrocles tornou-se discípulo de Crates e também que ele atingiu uma alta posição na filosofia. Temos aqui a confirmação da conversão de Metrocles ao

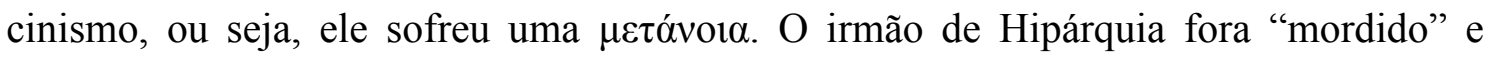
sofreu uma transformação. Ele percebeu que todo o seu sentimento de aỉó́s era algo que fora construído pela sociedade em que vivia. E que tal sentimento era desprovido de $\lambda$ ó $\gamma$ os tendo em vista que era completamente baseado numa $\delta$ ó $\xi \alpha$ popular, construída e moldada durante muito tempo. Ele percebeu que era exatamente isto que causava a "neblina" em seu $\lambda$ ójos, tornando-o escravo de tais convenções. Metrocles percebeu que aquele homem simpático e agradável, livre de posses e de riqueza, era na verdade, um homem realmente livre, e também que ele era, como seu próprio nome diz, senhor,

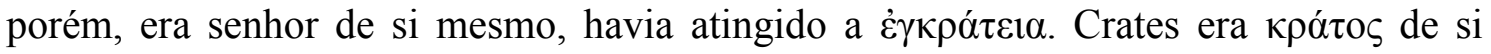
mesmo.

Esse autodomínio, evidente em Crates, não era evidente nas demais escolas. Como já foi dito, Metrocles era um peripatético, discípulo de Teofrasto, mas também sabemos, por outras fontes, que ele também já fora um discípulo do platônico Xenócrates. ${ }^{24}$ Provavelmente ele também percebeu que estudando com Xenócrates, as

\footnotetext{
${ }^{24}$ Discípulo de Platão e terceiro escolarca da Academia, sucedeu Espeusipo, o sobrinho de Platão e segundo escolarca da Academia.
} 
forças "alienígenas" seriam senhor de si mesmo. ${ }^{25}$ Ou seja, o resultado seria que as convenções seriam senhor de Metrocles. Donald Dudley, utilizando uma passagem de Teles, resume bem tal ideia:

Metrocles diz que, quando ele estudou com Teofrasto e Xenócrates, embora ele tivesse uma permissão liberal da casa, ele estava realmente com medo da fome, e estava constantemente em um estado de carência e penúria. Mas quando ele se transferiu para Crates, ele poderia ter mantido uma segunda pessoa além de si mesmo sem qualquer abono. Pois antigamente era essencial ter sandálias [...] um manto, um séquito de criados, um lar bem mobiliado, para contribuir para a mesa comum, pão de trigo, guloseimas acima do nível comum, vinho doce, e para mobiliar os entretenimentos que lhe sucederam. Tal modo de vida era considerado liberal. Mas quando ele mudou para se tornar um seguidor de Crates, não havia nada disso. Vivendo em uma escala muito mais simples, ele estava satisfeito com um manto áspero, pão de cevada e ervas comuns, e não sentia arrependimento por seu antigo modo de vida nem insatisfação com a do presente. Se ele quisesse se ungir, iria para os banhos e usaria borras de óleo; às vezes também ia para as fornalhas dos ferreiros, assava uma espadilha, misturava um pouco de óleo, sentava-se e fazia o café da manhã. No verão, ele dormia nos templos, e no inverno, nos banhos. No entanto, não havia nenhum desejo ou penúria anterior, ele era suficiente para suas circunstâncias e não sentia desejo por servos. (TELES apud DUDLEY, 1937, p. 47-48, tradução nossa.)

Com isto notamos que Metrocles, mesmo unindo-se com filósofos consagrados não conseguiu extirpar-se das convenções. Em Crates, por outro lado, ele de fato vira um homem que conseguiu colocar-se acima de qualquer convenção social.

Existem dois pontos que merecem ainda ser observados: 1) Crates, antes mesmo de ser mestre de Metrocles, não nutria boas considerações acerca de Teofrasto e, consequentemente, de toda a filosofia peripatética; e 2) Crates, assim como Metrocles, também sofrera o mesmo tipo de humilhação na academia de ginástica, e isto também se dava devido a sua debilidade física.

Analisemos o primeiro ponto. Acerca disso, Diógenes Laércio nos conta uma interessante anedota, ele nos diz que:

Em certa ocasião [Crates] foi advertido pelos inspetores de polícia porque vestia roupas levíssimas de musselina ${ }^{26}$, e sua resposta foi: "Mostrar-vos-ei o próprio Teofrasto vestido de musselina!" Em face de sua incredulidade, Crates conduziu-os ao salão de barbeiro e mostrou Teofrasto sendo barbeado. (D.L VI. 90)

\footnotetext{
25 Pequeno trocadilho com o nome do filósofo, algo bem comum entre os filósofos cínicos,

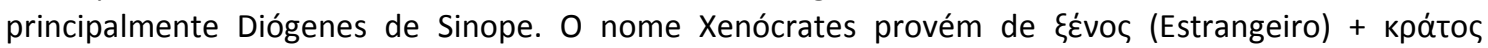
(senhor). Neste caso, literalmente, o nome significaria algo como "a força estrangeira".

${ }^{26}$ Um tipo tecido muito leve e fino, usado para fazer roupas femininas.
} 
A ideia por trás dessa anedota pode ter duas fontes, ambas do mestre de Crates, Diógens, o Cão. A primeira delas é uma zombaria com os atenienses, pois como constatamos em Diógenes Laércio, o Cão frequentemente zombava dos atenienses, como por exemplo quando foi questionado na estrada de onde estava vindo e para onde iria, sua resposta foi "dos aposentos dos homens para os das mulheres" (D.L. VI. 59) querendo dizer com isso que estava vindo da Lacedemônia e indo para Atenas. Ou seja, Crates se vestiu de mulher por estar em uma cidade de mulheres. A segunda fonte, que por sinal é a mais provável, é mais interessante. Ela provém do pensamento de Diógenes em sua República. Sabemos que lá o Cão lidara com a questão das mulheres, para ele homens e mulheres deveriam fazer e ter tudo em comum, inclusive a vestimenta (DUDLEY, 1937, p. 36). O ponto em questão é que a ideia de vestimenta não é uma convenção arbitrária e artificial, pois os seres humanos são por natureza desprovidos da capacidade de suportar por exemplo um frio intenso ou um calor excessivo, e que, por este motivo, faz-se necessário ter roupas para sua proteção, porém, apesar disso, para eles a ideia de uma vestimenta separada para homens e mulheres é, em si mesma, uma convenção social artificial. Ao usar uma roupa feminina, Crates está indo contra a convenção, ele está tentando desfigurar a moeda corrente. Por outro lado, ao mostrar Teofrasto sendo barbeado, ele está apontando para o fato de que Teofrasto é escravo das convenções, pois ao fazer sua barba no salão para ficar com um rosto tão liso e delicado como uma roupa de musselina ele demonstra vaidade, ele quer ter uma aparência bonita, ou seja, ele não desejava mostrar-se feio e relaxado perante os seus alunos em suas audiências públicas que, conforme Diógenes Laércio, chegava a ser mais de dois mil (D.L. VI. 37). Deste modo, Teofrasto era visto por Crates, como uma celebridade que era escrava das convenções sociais e que preocupava-se mais com a aparência e a reputação do que com a verdadeira sabedoria.

Quanto ao segundo ponto, encontramos também em Diógenes Laércio, que nos diz que:

Em suas anedotas, Zenão de Cítio $^{27}$ relata que Crates não teve a menor dificuldade em costurar uma pele de ovelha ao seu manto. Crates era feio de rosto, e quando fazia ginastica provocava riso. Erguendo as mãos, costumava dizer: "Coragem. Crates! Isso faz bem aos olhos e ao resto do corpo. Quanto aos que riem de ti, hás de vê-los, torturados pela doença, considerando-te feliz e recriminando-se por sua preguiça!"' (D.L. VI. 91,92)

\footnotetext{
${ }^{27}$ Discípulo de Crates e fundador do Estoicismo.
} 
Tal história também é relatada na apócrifa Carta 20 de Crates, que é destinada justamente à Metrcoles, no qual Crates diz:

Depois que você nos deixou em casa, desci à palestra dos rapazes e, depois de me ungir com óleo, fui correr. Quando os jovens me viram, eles começaram a rir, mas eu, para não cessar muito rapidamente de me exercitar, me exortei, dizendo: "Crates, você está labutando para os olhos, para a cabeça, para os ouvidos, para os pés." Eles me ouviram dizer isso e começaram a correr, e a partir daí não mais se ungiram com óleo, mas também continuaram se exercitando. Por essa razão, eles não estão sempre doentes, como antigamente. Eles me agradeceram por ser a causa de sua saúde e não me deixaram, mas continuaram a me seguir onde quer que eu fosse, ouvindo-me e imitando o que eu dizia e fazia. Eu estou escrevendo isso para você, também, pode correr, não sozinho, mas onde os jovens passam o tempo. Nós devemos prover à eles, já que a ação ensina a resistência mais rapidamente que as palavras, um princípio encontrado apenas na filosofia de Diógenes. (CRATES, Carta 20, tradução nossa)

Notamos em tais relatos que Crates também sofreu escárnio público na academia de ginástica. No entanto, ele conseguira superar com muita facilidade tais escárnios, fazendo inclusive, com que os seus escarnecedores percebessem que era eles que deveriam ser alvo do escárnio, simplesmente pelo fato de que eles estavam presos a tais "normas criadas" acerca da beleza física. Os jovens também perceberam que Crates era "senhor de si mesmo", e que ele não nutria dentro de si nenhum respeito e nenhuma consideração pelas convenções sociais. Tal aspecto moral chocara os jovens que passaram não só a admirar Crates, mas também a agradecer-lhe por ter-lhes mostrado o quão estúpidos eles estavam sendo.

Após tal conversão, vemos os ensinamentos recebidos e o progresso espiritual de Metrocles nas próximas três Cartas apócrifas de Crates, a 21, 22 e 23. Todas elas endereçadas ao irmão de Hipárquia. Na Carta 21, Metrocles ainda aparenta ter certo receio de utilizar o termo cínico, porém Crates escreve:

Contanto que você tenha medo do nome "Cínico", eu vou chamá-lo por esse nome, e você ainda tem muito medo disso. Você mesmo, ao escrever, nos dirigiu como "Cínico". E você aprenderá a fazer as outras coisas dessa maneira, se criar o hábito de não ter medo de palavras, não apenas para usá-las. Pois o caminho que conduz à felicidade através das palavras é longo, mas aquilo que conduz através das ações diárias é um regime abreviado. Mas as massas, embora desejem o mesmo fim que os Cínicos, fogem daqueles que pregam o regime, quando veem como é difícil. Não se deve tornar um Cínico por causa deste caminho, mas deve nascer um. Pois o regime é naturalmente mais eficaz do que o próprio caminho (CRATES, Carta 21 , tradução nossa). 
E na Carta 22, seguindo também o exemplo de Diógenes, o Cão, Crates ensina-lhe como e para quem deve-se mendigar, ele lhe diz:

Não implore de todos, mas apenas dos dignos, e não tome a mesma quantia de todos, mas aceite um óbolo do prudente e uma mina dos gastadores. Pois não se pode mais receber nada deles, como se pode com os prudentes, uma vez que desperdiçam seu dinheiro de maneira tão imprudente. (CRATES, Carta 22, tradução nossa).

Na Carta 23, a mais longa, Crates conta à Metrocles um famoso episódio de Diógenes, a saber: quando ele foi capturado por piratas e vendido como escravo. No entanto, Crates mostra a Metrocles como Diógenes soube superar tal acontecimento. O objetivo dele é mostrar que o sábio cínico pode ser senhor de si mesmo em qualquer situação.

Devido a tais ensinamentos que Diógenes Laércio conclui que Metrocles alcançou uma posição de relevo na filosofia. Precisou-se de tempo para formar Metrocles, não foi algo repentino, ele não tornou-se imune às convenções quando Crates peidou na sua frente, naquele momento ele apenas teve um insight, um tratamento de choque, um espanto! Conseguimos notar isso quando Metrocles, já mais velho, ensinava seus alunos dizendo que "das coisas algumas podem obter-se com dinheiro, como uma casa, outras com o tempo e diligência, como a educação" (D.L. VI. 95). Aqui, vemos o quão longe foi Metrcoles na אuvıкós ßíos. Ele de fato tornou-se parte da matilha.

E quanto a Crates? Ele era um homo cynicus, o único habitante da cidade de Pera após a morte de Diógenes, usara sua $\varphi \imath \lambda \alpha \nu \theta \rho \omega \pi i ́ \alpha$ para ajudar os homo sapiens sapiens de nosso planeta que estão imersos no mar de ilusão que envolve a cidade de Pera. Crates não era o Abridor de Portas somente pelo fato de entrar em qualquer casa para dar conselhos. Ele o era, acima de tudo, pelo fato de ser o Abridor de Portas da cidade de Pera para os habitantes que moravam ao redor, para que pudessem desfrutar e vislumbrar a mais alta felicidade. 


\section{REFERÊNCIAS}

ANNAS, J. The Morality of Happiness. New York: Oxford University Press, 1995.

ARISTOTLE. Nicomachean Ethics. Trad. Terence Irwin. Indianopolis: Hackett Publishing Company, 1999.

BRANHAM, R.B. Desfigurar a moeda. A retórica de Diógenes e a invenção do cinismo. In: BRANHAN, R.B \& GOULETCAZÉT, M.O. (ed.) Os cínicos: o movimento cínico na antiguidade e o seu legado. Tradução de Cecília Camargo Bartalotti. São Paulo: Loyola, 2007.

CÍCERO. De Finibus. Trad. Reynolds L.D. Oxford: Oxford University Press, 1998.

DUDLEY, D.R. A History of Cynicism. London: Methuen \& CO. LTD, 1937

FOUCAULT, M. A Coragem da Verdade. Trad. Marcos Marcionilo. São Paulo: WFM Martins Fontes, 2004.

FOUCAUlT, M. A Hermenêutica do Sujeito. Márcio Alves da Fonseca e Salma Tannus Muchail. São Paulo: WMF Martins Fontes, 2014.

GOULET-CAZÉT, M.O. Religião e os primeiros cínicos. In: BRANHAN, R.B \& GOULETCAZÉT, M.O. (ed.) Os cínicos: o movimento cínico na antiguidade e o seu legado. Tradução de Cecília Camargo Bartalotti. São Paulo: Loyola, 2007.

KRUEGER, D. O indecente e a sociedade. O despudor de Diógenes na cultura imperial romana. In: BRANHAN, R.B \& GOULETCAZÉT, M.O. (ed.) Os cínicos: o movimento cínico na antiguidade e o seu legado. Tradução de Cecília Camargo Bartalotti. São Paulo: Loyola, 2007.

LAÉRCIO, D. Vidas e Doutrinas dos Filósofos Ilustres. Trad. Mario da Gama Kury. Brasília: Editora UNB, 2008.

LONG, A.A. A tradição socrática: Diógenes, Crates e a ética helenística. In: BRANHAN, R.B \& GOULETCAZÉT, M.O. (ed.) Os cínicos: o movimento cínico na antiguidade e o seu legado. Tradução de Cecília Camargo Bartalotti. São Paulo: Loyola, 2007.

MALHERBE, A.J. The Cynic Epistles: A Study Edition. Atlanta: Society of Biblical Literature, 1977.

NAVIA, L.E. Classical Cynicism: A Critical Study. Greenwood: Greenwood Press, 1996.

NAVIA, L.E. Diógenes, o Cínico. Trad. João Miguel Moreira. São Paulo: Editora Odysseus, 2010. 
PROMETHEUS - N. 32 - January - April 2020 - E-ISSN: 2176-5960

PLATO. Meno. Trad. George Grube. Indianopolis: Hackett Publishing Company, 1980.

PRINCE, S. Antisthenes of Athens. Texts, Translations and Commentary. Ann Arbor: University of Michigan Press, 2015.

RUSSEL, D.C. Happiness For H'umans. Oxford: Oxford University Press, 2012. 